\title{
Prognostic factors and impact of peritoneal dialysis-related early peritonitis on mortality in Sardjito General Hospital, Yogyakarta, Indonesia
}

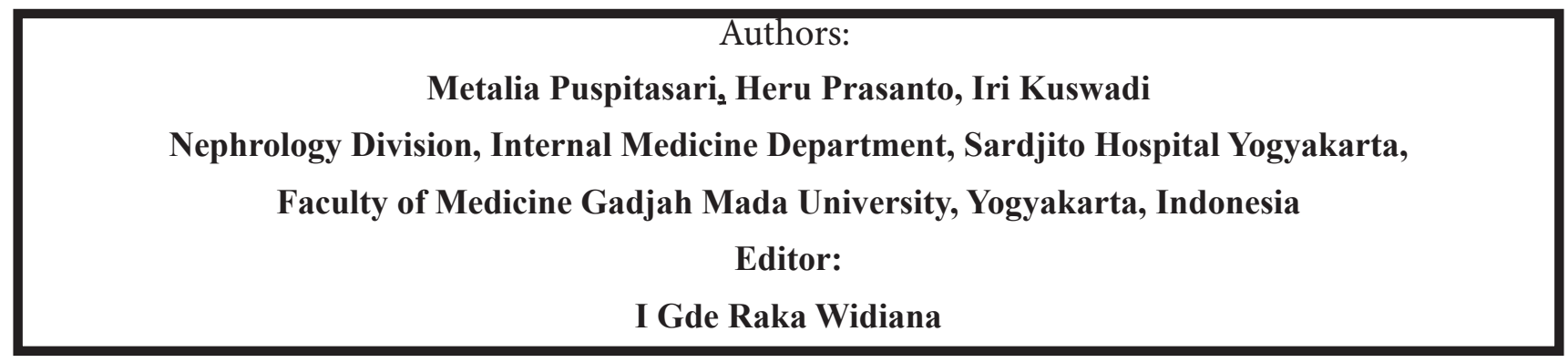

Received 18 May 20018, revised 10 September 2018, accepted 16 October 2018, published 1 December 2018

\section{Abstract}

Background Peritonitis has been reported to be associated with high mortality. However, information on the impact of the first peritonitis episode on continuous ambulatory peritoneal dialysis (CAPD) patients is sparse. ObjectiveTo determine the association between peritoneal dialysis-related early peritonitis and mortality. To determine prognostic factors on mortality in peritonitis patients with peritoneal dialysis. Methods A retrospective observational cohort study was conducted over 5 years at a single PD unit in Sardjito Hospital. Inclusion criteria: First onset of peritonitis patients with peritoneal dialysis from $2013-2017$, age $\geq 18$ years old. Exclusion criteria: Incomplete medical records. A total of 48 patients on CAPD with peritonitis was divided into the early onset of peritonitis ( $<20$ months) and late onset of peritonitis ( $\geq 20$ months. Kaplan-Meier survival curve was used to display cumulative relative risk as a parameter of prognostic factors. Results $A$ total of 48 patients (early onset of peritonitis, $n=31$; late onset of peritonitis, $\mathrm{n}=17$ ) were analyzed in our study with a mean of age 50.6 years consisted of males $64.6 \%$. There was a significant difference in patients' mortality between the early and late onset of peritonitis. The Kaplan-Meier analysis revealed that log-rank test, $\mathrm{p}<0.05$ with a mean survival time of patients with early peritonitis and late peritonitis was 236 days $(95 \%$ CI: 162-309 days) and 1702 days (95\% CI: 1067-2338 days) consecutively. Compared to those who were normoweight, underweight or overweight patients had increased risk of mortality, (RR 1.14 and 1.15; $p=0.003$, respectively). There was a significant association between diabetes mellitus and lower serum creatinine InaKidney | Vol. I | Is. 1| Sept - Dec 2018 levels, and the risk of mortality ( $R R$ 1.43, $p=0.03$ and mean difference $-6.01, \mathrm{p}<0.001$, respectively). Conclusions Early peritonitis patients have a poor prognosis compared to the late peritonitis group. Patients with shorter time to first peritonitis were prone to having a higher mortality rate. Diabetes mellitus, underweight or overweight, and lower serum creatinine are prognostic factors of mortality in peritonitis patients.

Keyword: peritonitis, peritoneal dialysis, mortality, prognostic factors

\section{Corresponding author:}

email: puspitasarimetalia@gmail.com (Puspitasari M)

\section{Introduction}

Continuous ambulatory peritoneal dialysis (CAPD) was first introduced as a renal replacement therapy in the late 1970s (1). Peritonitis is the most common serious complication of peritoneal dialysis (PD) and the leading cause of technique failure necessitating a switch to hemodialysis (HD), accounting for $42.6 \%$ of cases in Scotland, and $41.7 \%$ in London $(2,3)$. Many factors have been inconsistently linked with PD peritonitis, such as older age, female sex, race, nasal carriage of Staphylococcus aureus, diabetes mellitus, use of standard lactate dialysate compared with the novel biocompatible solution, hypoalbuminemia, low residual renal function and transfer from HD (2,4-10). 
A high peritonitis rate is associated with inferior technique and patient survival. However, few studies have extensively examined whether the timing of the first peritonitis episode has an impact on technique survival or patient survival of PD patients. We thus conducted a retrospective study on the incidence of mortality on CAPD patients over 5 years at a single medical center in Yogyakarta, Indonesia. The objectives of the study were to determine the association of onset of the first peritonitis episode and prognostic factors on mortality among peritonitis patients.

\section{Patients and Methods}

This was a retrospective observational cohort study. Complication of peritonitis in CAPD patients was screened from medical records at Sardjito Hospital, Yogyakarta, Indonesia between January 1, 2013, and December 31, 2017. Patients included in this study were aged 18 years or older, with the first onset of peritonitis and those with incomplete medical records were excluded.

A total of 48 patients on CAPD with peritonitis were divided into the early onset of peritonitis ( $<20$ months) and late-onset of peritonitis ( $\geq 20$ months). We set an optimal cut-off of 20 months as an optimal cut-off for early peritonitis is based on the previous study which used less than 20.28 months (3). The data collected included demography, body mass index, educational status, relevant biochemical data, the technique of insertion, co-morbid condition (cardiovascular disease, tuberculosis, urinary tract infection, pneumonia, diabetes mellitus, hypertension). A two-tailed p-value less than 0.05 was considered statistically significant. Chi-square and log-rank tests were used to test relative risk and prognostic factors. A prognostic factor is determined if an increased risk of the outcome happened in an exposed group of sick persons. Kaplan-Meier survival curve was used to describe survival time and relative risk. Statistical analysis was conducted using the statistical package for SPSS 16.0.

\section{Results}

Table 1 shows the baseline characteristics CAPD patients with peritonitis. A total of 48 patients (early onset of peritonitis, $n=31$; late onset of peritonitis, $n=17$ ) were analyzed in our study with an average age of 50.6 years (male, 64.6\%). They had low educational level (38\%), Normal body mass index 47\%, 33\% had diabetes mellitus and $46 \%$ had hypertension. There was no significant difference in mortality between early onset of peritonitis and late onset of peritonitis. There was no significant difference in gender, educational level, pneumonia, tuberculous, hypertension, the technique 28 of insertion and albumin levels on mortality. The Kaplan-Meier analysis revealed that log-rank test, $p<0.05$ with a mean survival time of patients with early peritonitis and late peritonitis was 236 days (95\% CI: $162-$ 309 days) and 1702 days (95\% CI: 1067-2338 days) consecutively, see figure 1 . Patients with underweight or overweight had increased the risk of mortality (RR 1.14 and 1.15 respectively, $p=0.003$ ), see table 1 . There was a significant association between diabetes mellitus and lower serum creatinine levels with increased risk of mortality $(R R=1.43, p=0.03$ and mean difference $-6.01, \mathrm{p}<0.001$, respectively), see table 1 and 2 .

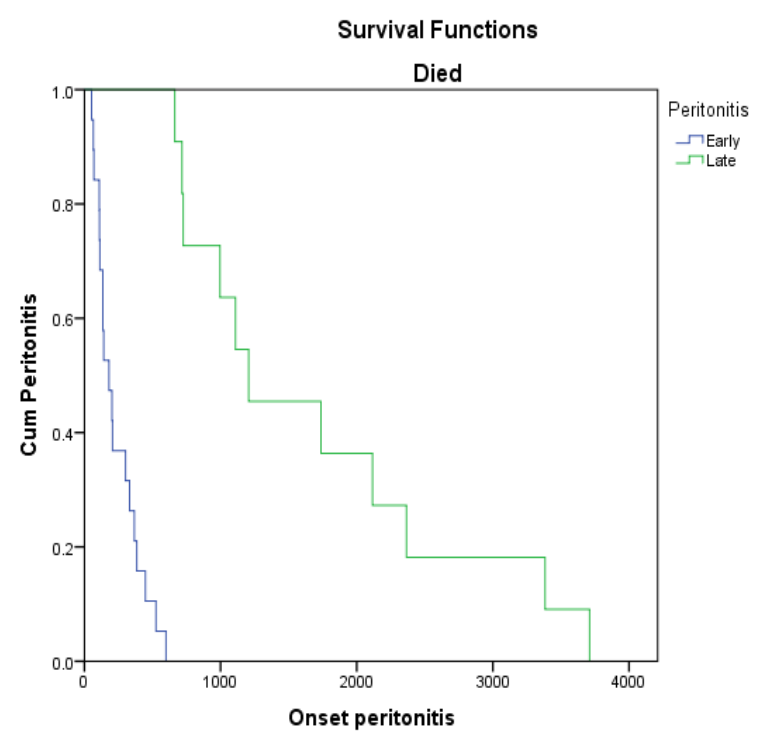

Figure 1. Kaplan Meier survival analysis according to the timing of the first peritonitis

\section{Discussion}

Peritonitis is one of the major complications of PD and despite a reduction in overall peritonitis rates, remains the primary reason patients switch from PD and mortality. Nowadays, the focus has been on strategies to improve peritonitis outcomes in addition to lowering the peritonitis incidence. There was a significant difference between early and late peritonitis with mortality in the present study. This data has the same result from other research in Taiwan, which early peritonitis patients were associated with worse technique survival, patient survival and stay on PD than late peritonitis patients, as indicated by Kaplan-Meier analysis (3). A Greek study of 47 CAPD or automated peritoneal dialysis (APD) patients by Fourtounas et al. reported that patients who developed peritonitis during the first year after starting PD were more prone to not only suffered from repeated episodes of peritonitis but also decreased technique survival. (11).Peritonitis rate was a predictor for mortality in whites, non-diabetes, and those over the age of 60 (12) and for every 0.5 episodes per year increase 


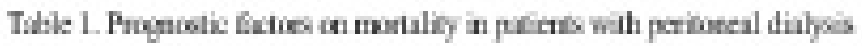

\begin{tabular}{|c|c|c|c|c|}
\hline \multirow[t]{2}{*}{ Trints } & \multicolumn{2}{|c|}{ Tilsont } & \multirow[t]{2}{*}{ MH } & \multirow[t]{2}{*}{ Priture } \\
\hline & De:hNol & Gruve MG & & \\
\hline 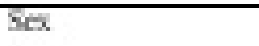 & & & & DIRA \\
\hline Mhis: & $1771 \%$ & 6x.11 & 0.719 & \\
\hline Fomils & $1110 \mathrm{H}$ & $0 \mathrm{~m}$ & $\mathrm{Br}$ & \\
\hline Flustinn & & & & 0 hs \\
\hline Hyt Bhal & $1+m$ & 17 & 23 & \\
\hline Diphom & 41: & $1+10$ & Din & \\
\hline Trikngahik & Loing & 91211 & ont? & \\
\hline Priprolists & 266 & 104 & $\mathrm{rel}$ & \\
\hline HMII & & & & $010 \mathrm{~s}$ \\
\hline Introtighl & 5(M0) & $0 \mathrm{~m}$ & L.14 & \\
\hline Mant & $17|\mathrm{~B}|$ & 521 & Bei & \\
\hline Gutweigh-htse & $8 \omega 0$ & 14II & L.IS & \\
\hline Proirmati & & & & 10 \\
\hline $\mathrm{Ys}$ & IOAB] & 2(LT) & 10 & \\
\hline $\mathrm{Mu}$ & MAKI) & 4UET & Reí & \\
\hline Tultrubus & & & & 10 \\
\hline $\mathrm{Ys}$ & $4=0$ & $1+10$ & 0.787 & \\
\hline Nu & MikI) & 5(LEI) & $\mathrm{ReI}$ & \\
\hline Diskis melitw: & & & & 001 \\
\hline Yes & lbinoy & $0 \mathrm{~m}$ & L4] & \\
\hline No & $4+10$ & 600 & Ber & \\
\hline Hytaiminn & & & & 005 \\
\hline Ys & $16(727\}$ & 64273 & 0.71 & \\
\hline Mu & $1+10 \%$ & $0 \mathrm{tg}$ & ReI & \\
\hline lrathe buthip & & & & 0.Lh \\
\hline Itwintipe & $3(60)$ & 240 & 022 & \\
\hline axn & $27\{\mathrm{~K} T\}$ & $4 \operatorname{ling}$ & $\mathrm{BeI}$ & \\
\hline Alhurit I evt & & & & $0 \%$ \\
\hline-3 grill & $15,(9)$ & 240 & 30 & \\
\hline $2-1 \mathrm{~g}$ & 915 & 345 & Ret & \\
\hline Periuats & & & & 10 \\
\hline Fuly ant & $18(\mathrm{Ka})$ & $4(17.4)$ & 025 & \\
\hline Lak-4at & 1. [A 4 in) & $2(154)$ & Reí & \\
\hline
\end{tabular}

Table 2. Biochemical parameters on mortality in patients with peritoneal dialysis

\begin{tabular}{lllll}
\hline \multicolumn{1}{c}{ Variable } & \multicolumn{2}{c}{ Outcome } & Mean difference & p-value \\
& $\begin{array}{c}\text { Death } \\
\text { Mean } \pm \text { SD }\end{array}$ & $\begin{array}{c}\text { Survive } \\
\text { Mean } \pm \text { SD }\end{array}$ & & \\
\hline BUN $(\mathrm{mg} / \mathrm{dl})$ & $36.9 \pm 18.93$ & $56.02 \pm 33.20$ & -19.12 & 0.06 \\
\hline Creatinine $(\mathrm{mg} / \mathrm{d})$ & $7.32 \pm 2.67$ & $13.34 \pm 4.47$ & -6.01 & $<0.001$ \\
\hline
\end{tabular}


in the peritonitis rate, the risk of mortality increased $10 \%$ in whites, $4 \%$ in non-diabetes and $11 \%$ in those over the age of 60 . In a Spanish study, the incidence of peritonitis was a strong predictor of peritonitis-related death and showed a clear trend to predict overall mortality (13). Peritonitis rate also predicted technique failure and mortality in a Turkish report (14).

Prognostic factors for peritonitis outcome have been found to include age, gender, race, diabetes, residual renal function, time on PD, concurrent exit site infection, cytokines, inflammatory markers, albumin, causative organisms, recent antibiotic therapy and recurrent peritonitis (15-21). Peritonitis is associated with significant morbidity, PD catheter loss, and switch to HD, transient or permanent ultrafiltration failure, possible permanent membrane damage, and even death $(13,14,22)$. Reports from the United States have also shown that mortality rate directly caused by peritonitis is less than $5 \%$ and related to specific pathogens $(23,24)$. In one retrospective Spanish study of 565 patients, 41 of the observed 693 episodes of peritonitis resulted in death $(5.9 \%)(13)$. The mean overall time to the first episode of peritonitis after the commencement of PD was 26.4 \pm 22 months in the entire cohort, higher than our study, 433 days (95\% CI: 75-792 days) (25).

Diabetes mellitus is associated with faster decline of residual renal function in PD patients (26-28). When residual renal function declines, the dialysis adequacy may be maintained only by more exchanges (enhancing the risk of peritonitis) or increased fill volumes. In addition, altered immunity of peritoneal defenses in diabetes as evidenced by impaired migration of phagocytes into the peritoneum and suppression of phagocytosis by advanced glycation end products (29). Furthermore, intestinal bacterial overgrowth due to low intestinal motility or slower colonic transit in diabetes may also increase the risk of peritonitis. The above reasons or mechanisms could partly explain why the early peritonitis group tended to be more diabetic in our study.

In the present study, we analyzed the data of peritonitis patients and found that underweight and overweight increase the risk of mortality. In a study conducted in India, found that the risk of mortality was significantly greater for underweight diabetic PD patients than those in the reference category(30). On the other hand, a report from Australia and New Zealand dialysis transplant registry shows that higher BMI was associated with a shorter time to first peritonitis episode, independent of other risk factors(31). In Asian PD patients, the relationship between BMI and mortality was U-shaped, with higher mortality in the underweight and obese patients. The increased mortality in obese patients was more prominent in patients with di30 abetes (32). The "U-shaped" association between BMI and mortality risk among Asian PD patients could be explained with adverse effects from malnutrition and obesity. Underweight PD patients are associated with the Protein-energy Wasting (PEW) status, and consequent loss of muscle and fat mass and cachexia (33), accompanied with chronic inflammation status (34), and obesity is closely associated with a greater chance of metabolic complications due to excessive absorption of carbohydrate, high serum triglycerides, coronary calcification, catheterization failure and abdominal herniation(35-37). Meanwhile, under the exposure of glucose load in PD solution which promotes obese, the PD patients easily gain higher BMIs. Moreover, as peritonitis is a well-known risk factor leading to increased mortality among the PD patients(31), Prasad et al (38) demonstrated that the obese PD patients had a 3.4 times greater risk of occurrence of peritonitis than that of normal BMI patients.

Limitations of our study, first, we do not exclude confounding factors such as socioeconomic condition and the rate of decline of residual renal function to bias the study results. Secondly, our single-center study results cannot be extrapolated to other centers and sufficiently large sample size involving many centers is needed.

In conclusion, Early peritonitis patients having a poor prognosis. Patients with shorter time to first peritonitis were prone to having a higher mortality rate. Diabetes mellitus, underweight or overweight and lower serum creatinine are prognostic factors of mortality in peritonitis patients.

\section{Acknowledgments}

Diah Pratiwi (Kalbe), RetnoPalupi (Pediatrician in Sardjito Hospital), Dewi Ismi Masithoh (Clinical Epidemiology and Biostatistics Unit), Cahyo (Nurse of peritoneal dialysis in Sardjito Hospital) and all the doctors and nurses who contributed to this research.

\section{Disclosure}

The authors have no financial or other conflicts of interest to declare

\section{References}

1. Oreopoulos DG, Robson M, Faller B, Ogilvie R, Rapoport A, deVeber GA. Continuous ambulatory peritoneal dialysis: a new era in the treatment of chronic renal failure. Clin Nephrol $1979 ; 11: 125-8$

2. Kavanagh D, Prescott GJ, Mactier R. PeritoInaKidney | Vol. I | Is. 1| Sept - Dec 2018 
neal dialysis associated peritonitis in Scotland 1999-2002. Nephrol Dial Transplant 2004; 19:2584-91

3. Yao-Peng H, Shu-Chuan W, Chia-Chu C, YaoKi W, Ping-Fanf C, Yu Y. The Negative Impact of early Peritonitis on Continous Ambulatory Peritoneal Dialysis Patients. Peritoneal Dialysis International 2013; 34: 627-35

4. Han SH, Lee SC, Ahn SV, Lee JE, Kim DK, Lee $\mathrm{TH}$, et al. Reduced residual renal function is a risk of peritonitis in continuous ambulatory peritoneal dialysis patients. Nephrol Dial Transplant 2007; 22:2653-8.

5. Ahmad S, Sehmi JS, Ahmad-Zakhi KH, Clemenger M, Levy JB, Brown EA. Impact of new dialysis solutions on peritonitis rates. Kidney Int 2006; (Suppl 103): S63-6.

6. Furkert J, Zeier M, Schwenger V. Effects of peritoneal dialysis solutions low in GDPs on peritonitis and exit-site infection rates. Perit Dial Int 2008; 28:637-40.

7. Montenegro J, Saracho R, Gallardo I, Martínez I, Muñoz R, Quintanilla N. Use of pure bicarbonate-buffered peritoneal dialysis fluid reduces the incidence of CAPD peritonitis. Nephrol Dial Transplant 2007; 22:1703-8.

8. Lim CT, Wong KS, Foo MW. The impact of topical mupirocin on peritoneal dialysis infection rates in Singapore General Hospital. Nephrol Dial Transplant 2005; 20:1702-6.

9. Nessim SJ, Bargman JM, Austin PC, Nisenbaum R, Jassal SV. Predictors of peritonitis in patients on peritoneal dialysis: results of a large, prospective Canadian database. Clin J Am SocNephrol 2009; 4:1195-200.

10. Rabindranath KS, Adams J, Ali TZ, Daly C, Vale L, Macleod AM. Automated vs continuous ambulatory peritoneal dialysis: a systematic review of randomized controlled trials. Nephrol Dial Transplant 2007; 22:2991-8.

11. Fourtounas C, Savidaki E, Dousdabanis P, Hardalias A, Kalliakmani P, Papachristou E, et al. Peritonitis during the first year after commencement of peritoneal dialysis has an impact on technique survival and patient morbidity. AdvPerit Dial 2006;22:50-4.

12. Fried LF, Bernardini J, Johnston JR, Piraino B. Peritonitis influences mortality in peritoneal dialysis patients. J Am SocNephrol 1996;
7:2176-82.

13. Pérez Fontan M, Rodríguez-Carmona A, García-Naveiro R, Rosales M, Villaverde P, Valdés F. Peritonitis-related mortality in patients undergoing chronic peritoneal dialysis. Perit Dial Int 2005; 25:274-84.

14. Sipahioglu MH, Aybal A, Unal A, Tokgoz B, Oymak O, Utas C. Patient and technique survival and factors affecting mortality on peritoneal dialysis in Turkey: 12 years' experience in a single center. Perit Dial Int 2008; 28(3):23845 .

15. Krishnan M, Thodis E, Ikonomopoulos D, Vidgen E, Chu M, Bargman JM, et al. Predictors of outcome following bacterial peritonitis in peritoneal dialysis. Perit Dial Int 2002; 22(5):57381.

16. Yang CY, Chen TW, Lin YP, Lin CC, Ng YY, Yang WC, et al. Determinants of catheter loss following continuous ambulatory peritoneal dialysis peritonitis. Perit Dial Int 2008; 28(4):361-70.

17. Golper TA, Brier ME, Bunke M, Schreiber MJ, Bartlett DK, Hamilton RW, et al. Risk factors for peritonitis in long-term peritoneal dialysis: the Network 9 peritonitis and catheter survival studies. Am J Kid Dis 1996; 28:428-36.

18. Troidle L, Gorban-Brennan N, Kliger AS, Finkelstein FO. Effect of duration of chronic peritoneal dialysis therapy on the development of peritonitis. Perit Dial Int 1999; 19:376-9.

19. Elsurer R, Afsar B, Sezer S, Ozdemir FN: Peritoneal cells at admission: do they have prognostic significance in peritonitis? Ren Fail 2010; 32:335-42.

20. Chow KM, Szeto CC, Cheung KK, Leung CB, Wong SS, Law MC, et al. Predictive value of dialysate cell counts in peritonitis complicating peritoneal dialysis. Clin J Am SocNephrol 2006; 1:768-73.

21. Szeto CC, Wong TY, Chow KM, Leung CB, Li PK. The clinical course of culture-negative peritonitis complicating peritoneal dialysis. Am J Kidney Dis 2003; 42(3):567-74.

22. Woodrow G, Turney JH, Brownjohn AM. Technique failure in peritoneal dialysis and its impact on patient survival. Perit Dial Int 1997; 17(4):360-4.

23. Mujais S. Microbiology and outcomes of peri- 
tonitis in North America. Kidney Int 2006; 70(Suppl 103): S55-62.

24. Bunke CM, Brier ME, Golper TA. Outcomes of single organism peritonitis in peritoneal dialysis: gram negatives versus gram positives in the Network 9 Peritonitis Study. Kidney Int 1997; 52(2):524-9.

25. Harel Z, Wald R, Bell C, Bargman JM. Outcome of patients who develop early-onset peritonitis. AdvPerit Dial 2006; 22:46-9.

26. Liao CT, Shiao CC, Huang JW, Hung KY, Chuang HF, Chen YM, et al. Predictors of faster decline of residual renal function in Taiwanese peritoneal dialysis patients. Perit Dial Int 2008; 28(Suppl 3): S191-5.

27. Johnson DW, Mudge DW, Sturtevant JM, Hawley CM, Campbell SB, Isbel NM, et al. Predictors of decline of residual renal function in new peritoneal dialysis patients. Perit Dial Int 2003; 23:276-83.

28. Singhal MK, Bhaskaran S, Vidgen E, Bargman JM, Vas SI, Oreopoulos DG. Rate of decline of residual renal function in patients on continuous peritoneal dialysis and factors affecting it. Perit Dial Int 2000; 20:429-38

29. Liu BF, Miyata S, Kojima H, Uriuhara A, Kusunoki H, Suzuki K, et al. Low phagocytic activity of resident peritoneal macrophages in diabetic mice: relevance to the formation of advanced glycation end products. Diabetes 1999; 48:2074-82

30. Prasad N, Sinha A, Gupta A, Sharma RK, Bhadauria D, Chandra A, et al. Effect of body mass index on outcomes of peritoneal dialysis patients in India. Perit Dial Int 2014; 34(4): 399408

31. McDonald SP, Collins JF, Rumpsfeld M, Johnson DW, Obesity is a risk factor for peritonitis in the Australian and New Zealand peritoneal dialysis patient population. Perit Dial int 2004; 24(4): 340-6

32. Kiran VR, Zhu TY, Yip T, Lui SL, Lo WK, Body mass index, and mortality risk in Asian-peritoneal dialysis patients in Hong Kong-Impact of diabetes and cardiovascular disease status. Perit Dial Int 2014; 34(4): 390-398

33. Obi Y, Qader H, Kovesdy CP, Kalantar-Zadeh $\mathrm{K}$, Latest consensus and update on protein-energy wasting in chronic kidney disease. Current opinion in clinical nutrition and metabolic care 2015; 18(3): 254-62

34. Stenvinkel P, Heimburger O, Paultre F, Diczfalusy U, Wang T, Berglund L et al. Strong association between malnutrition, inflammation, and atherosclerosis in chronic renal failure. Kidney Int 1999; 55(5): 1899-911

35. Thamer M, Hwang W, Fink NE, Sadler JH, Wills S, Levin NW et al. US nephrologists' recommendation of dialysis modality: results of a national survey. American journal of kidney diseases: the official journal of the National Kidney Foundation 2000; 36 (6): 1155-65

36. Nolph KD, Sorkin M, Rubin J, Arfania D, Prowant B, Fruro L et al. Continous ambulatory peritoneal dialysis: three-year experience at one center: Annals of internal medicine 1980; 92(5): 609-13

37. Kalantar-Zadeh K, Abbott KC, Salahudeen AK, Kilpatrick RD, Horwich TB, Survival advantages of obesity in dialysis patients. The American journal of clinical nutrition 2005; 81(3): 543-54

38. Prasad N, Sinha A, Gupta A, Sharma RK, Bhadauria D, Chandra A et al. Effect of body mass index on outcomes of peritoneal dialysis patients in India. Peritoneal dialysis international 2014; 34(4): 399-408 
